\title{
Twiddler's syndrome in patient with single chamber pacemaker
}

\author{
Muhammad Munawar, Ingrid Pardede, Dian L. Munawar, Jimmy Pambudi \\ Binawaluya Cardiac Center, Jakarta, Indonesia
}

\begin{abstract}
Abstrak
Sindrom 'twiddler' telah lama diketahui sebagai komplikasi pemasangan pacu-jantung. Sindrom tersebut ditandai dengan berputarnya lead atau kabel pada sumbu panjang generator pacu-jantung sehingga menimbulkan lilitan lead. Lead akan rusak, sehingga kawat putus atau terjadi bocor insulasi lead. Keadaan ini dapat menyebabkan lead terlepas dari tempatnya, stimulasi diafragma, gerakan tertentu lengan atas yang disebabkan oleh stimulasi pleksus saraf brakialis dan hilangnya fungsi pacuan ke jantung. Mengetahui faktor risiko terjadinya sindroma ini dan melakukan tindakan pencegahan merupakan hal yang sangat penting. Kami melaporkan seorang laki-laki berumur 84 tahun yang memutar generator pacujantung kamar tunggal secara tidak sengaja sehingga timbul sindrom 'twiddler' dalam waktu 2 bulan yang menyebabkan bocor insulasi lead sehingga baterei habis. Sepanjang pengetahuan penulis, ini merupakan laporan kasus pertama di Indonesia. (Med J Indones 2011; 20:295-7)
\end{abstract}

\begin{abstract}
Twiddler's syndrome is a well-known complication of pacemaker treatment. This syndrome is characterized by coiling of the pacemaker lead due to the rotation of pacemaker generator on its long axis. Lead damage could cause lead facture or insulation leakage. The syndrome is also responsible for lead dislodgment, diaphragmatic stimulation, twitching upper arm due to plexus brachial nerve stimulation and loss of capture. Understanding risk factors and preventive measurement is very important. In this case report we present an 84 year-old patient who managed to rotate his single chamber pacemaker generator unintentionally following implantation in which the syndrome occurred within 2 months causing insulation leakage and battery depletion. For the best of our knowledge, this is the first report of twiddler's syndrome in Indonesia. (Med J Indones 2011; 20:295-7)
\end{abstract}

Key words: lead damage, long axis rotation, pacemaker, twiddler's syndrome

Twiddler's syndrome is a rare complication of pacemaker implantation, first described by Bayliss et al. in $1968,{ }^{1}$ when a patient manipulated and rotated the pulse generator in the pocket resulting in lead dislodgement, diaphragmatic stimulation and loss of capture. The latter can be life-threatening in a pacemaker-dependent patient.

In this case report, we describe a patient with a single chamber pacemaker who managed to rotate his single chamber pulse generator following implantation causing tingled due to rotation of the pacemaker generator on its long axis and dislodgement of the lead.

\section{CASE REPORT}

A 84-year-old man, was admitted to our emergency department because of sudden onset of diaphragmatic stimulation, twitching of the right upper extremity and severe bradycardia due to loss capture of his pacemaker (figure 1). No history of having stroke, but he has suffered from dementia over the last 2 years. He had been complaining of fatigue and light headiness for the past 6 months.

Three months ago, he underwent pacemaker implantation of VVIR (Medtronic SSIR, Minneapolis, MN,
USA) due to severe bradycardia and atrial fibrillation at another hospital. The approach for the implantation was from cephalic vein. The electrode was tine lead, passive fixation (5092 model Medtronic, Minneapolis, MN, USA) ventricular lead with bipolar configuration and was securely placed at the right ventricular apex. The $\mathrm{R}$ wave was 8.7 $\mathrm{mV}$, and the pacing threshold was quite good $(0.4 \mathrm{~V})$ and the impedance was $830 \mathrm{ohm}$ at the time of implantation. The lead was a ligature to the pectoralis muscle with nonabsorbable silk around suture-sleeves. The pacemaker was placed at the subcutaneous tissue regarded as standard implantation and was completed in about $35 \mathrm{~min}$.

When he was at our emergency department, physical examination revealed his arterial blood pressure was $120 / 70 \mathrm{mmHg}$ and his pulse rate was 34/min. Cardiac auscultation findings were normal. A pulsation in his abdomen due to diaphragmatic stimulation was observed. The right extremity twitching was also observed. Programming pacemaker confirmed there was insulation leakage and the impedance was very low $(<100 \mathrm{ohm})$ leading to battery depletion. Neither sensing nor pacing was possible (figure 1).

On chest X-rays taken at our hospital, the tip of ventricular lead was in the distal cephalic vein, and there was coaxial twisting of the lead around the pacemaker generator (Figure 2). 
The patient was brought into cathlab, and temporary pacemaker was inserted. The damaged lead was removed without any complication. ${ }^{2}$ Because both lead and pulse generator were damaged (figure 3), a new VVI pulse genitor set was implanted without any difficulties. The lead was positioned at the mid septal of the right ventricle. The new pocket was made intra-pectoral muscle and pulse generator was sutured to surrounding tissues with un-absorbable suture. On 12 months follow-up, he is well and the pacemaker was having normal function.

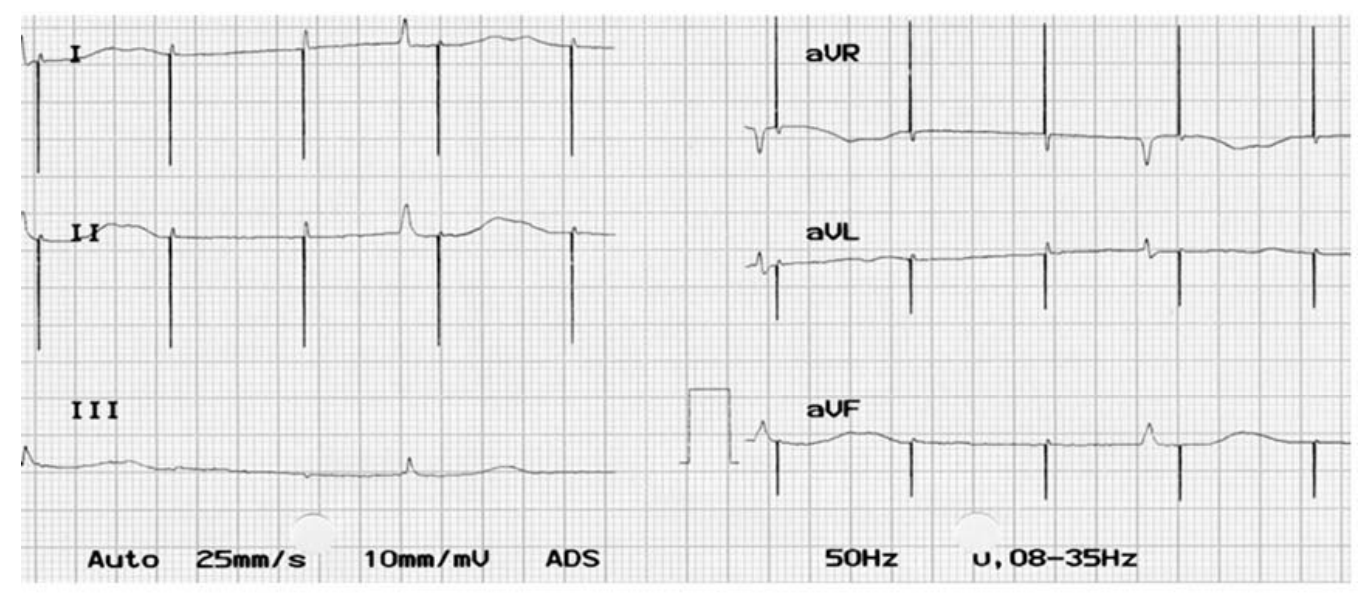

Figure 1. Surface ECG tracing revealed loss of capture of spike of the pacemaker without any sensing. There is severe bradycardia with fine atrial fibrillation

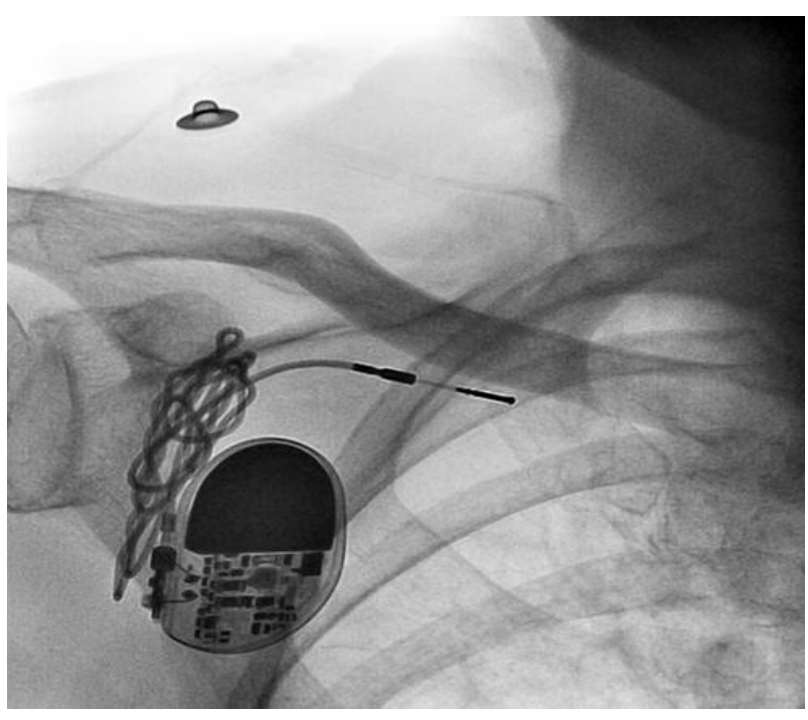

Figure 2. X-ray finding showed the tip of the lead located at the ostium of the cephalic vein and coiling around pulse generator pocket.

\section{DISCUSSION}

Twiddler's syndrome is a very rare complication of pacemaker implantation. The syndrome occurs more often among elderly, obese, dementia, and mentally disorder patients. ${ }^{3-5}$ Previous reports have noted a tendency of complication of twiddler's syndrome in women, suggesting lax subcutaneous tissue along the pendulous breast that may potentially form a large loose pocket. ${ }^{6,7}$ Children may be more at risk

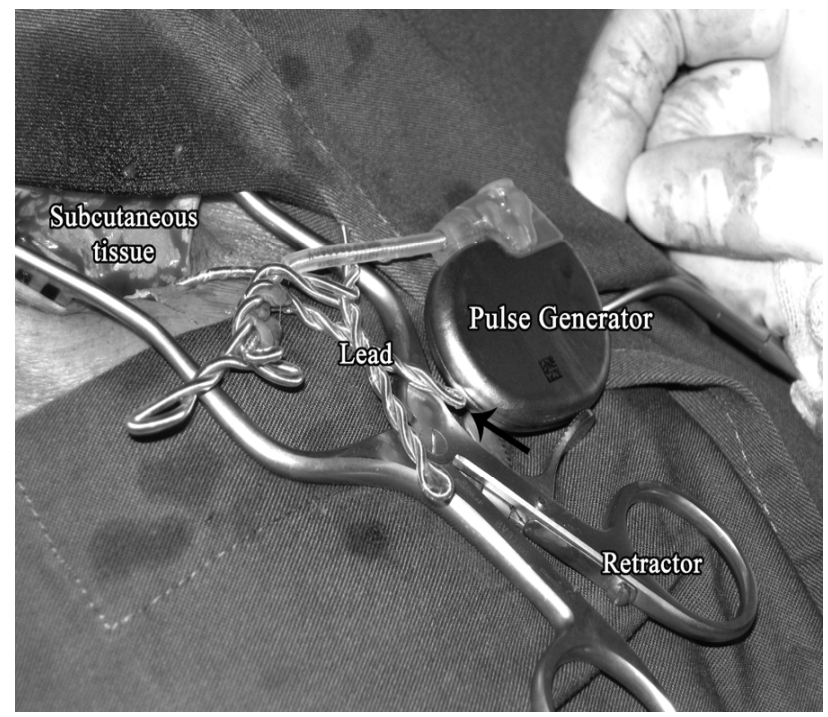

Figure 3. Proximal part of the lead with many twists during lead removal

of twiddler's syndrome. Children's understanding of the possible consequences of twiddling is poor and access to the generator and lead is easier because they have thinner subcutaneous tissue. ${ }^{8}$ Although the syndrome was reported in pacemakers patients, ${ }^{1,9,10}$ it is also now recognized in patients with implantable cardioverter-defibrillator leading to or causing its failure. ${ }^{11-13}$ This complications usually occurs in the first year of implantation, ${ }^{14}$ although there is a report of late occurrence. ${ }^{15}$ 
Most of the twiddler's syndrome causes lead fracture and increase in impedance lead. ${ }^{8,16}$ In our case, this is very unusual because there is a leakage of the lead insulation and in turn causing battery depletion.

The cardiac symptomatology usually present as phrenic stimulation by lead dislodgement producing diaphragmatic stimulation or arm twitching caused by brachial plexus stimulation. ${ }^{4,17}$

As general population grows older, it is reasonable to expect an increase in the incidence of cardiovascular implantable electronic device implantation. In substantial proportion of this elderly population, there is an expected increased prevalency of dementia, thus the incidence of the syndrome may increase in the future.

The syndrome can be avoided by minimizing pocket size and suturing the device to surrounding tissues. ${ }^{14}$ Other preventive measures include using a compression band around the upper chest and shoulder, and tightening of the patient's arm for at least five to seven days. ${ }^{17}$ The use of a Dacron patch would stabilize the pulse generator by promoting tissue in-growth. The necessity for careful follow-up, especially in the first few months after surgery, needs to be underscored. The use of a Dacron pouch and adequate fixation of the device header should be strongly considered for patients at risk. ${ }^{18,19}$ For the best of knowledge, this is the first case reported in Indonesia.

\section{REFERENCES}

1. Bayliss CE, Beanlands DS, Baird RJ. The pacemakertwiddler's syndrome: A new complication of implantable transvenous pacemakers. Can Med Assoc J. 1968;99:371-3.

2. Wilkoff BL, Love CJ, Byrd CL, Bongiorni MG, Carrillo RG, Crossley GH, 3rd, Epstein LM, Friedman RA, Kennergren CE, Mitkowski P, Schaerf RH, Wazni OM. Transvenous lead extraction: Heart rhythm society expert consensus on facilities, training, indications, and patient management: This document was endorsed by the american heart association (aha). Heart Rhythm. 2009;6:1085-104.
3. Castillo R, Cavusoglu E. Twiddler's syndrome: An interesting cause of pacemaker failure. Cardiology. 2006;105:119-21.

4. Nicholson WJ, Tuohy KA, Tilkemeier P. Twiddler's syndrome. N Engl J Med. 2003;348:1726-1727

5. Newland GM, Janz TG. Pacemaker-twiddler's syndrome: A rare cause of lead displacement and pacemaker malfunction. Ann Emerg Med. 1994;23:136-8.

6. Khalilullah M, Khanna SK, Gupta U, Padmavati S. Pacemaker twiddler's syndrome: A note on its mechanism. J Cardiovasc Surg (Torino). 1979;20:95-100.

7. Terzi RG, Hutchin P. The migrating electrode. Complication of transvenous electrical pacing of the heart. Ann Thorac Surg. 1968;6:458-62.

8. Abrams S, Peart I. Twiddler's syndrome in children: An unusual cause of pacemaker failure. Br Heart $\mathrm{J}$. 1995;73:190-2.

9. Weiss D, Lorber A. Pacemaker twiddler's syndrome. Int J Cardiol. 1987; 15:357-60.

10. Meyer JA, Fruehan CT, Delmonico JE, Jr. The pacemaker twiddler's syndrome. A further note. J Thorac Cardiovasc Surg. 1974;67:903-7.

11. Mehta D, Lipsius M, Suri RS, Krol RB, Saksena S. Twiddler's syndrome with the implantable cardioverter-defibrillator. Am Heart J. 1992;123:1079-82.

12. Robinson LA, Windle JR. Defibrillator twiddler's syndrome. Ann Thorac Surg. 1994;58:247-9.

13. Ruder MA, Mead RH, Smith NA, Winkle RA. Defibrillator "twiddler's" syndrome. Pacing Clin Electrophysiol. 1990;13:1073-4.

14. Fahraeus T, Hoijer CJ. Early pacemaker twiddler syndrome. Europace. 2003;5:279-81.

15. Dursun I, Yesildag O, Soylu K, Yilmaz O, Yasar E, Meric M. Late pacemaker twiddler syndrome. Clin Res Cardiol. 2006;95:547-9.

16. Csanadi Z, Hegedus Z, Csanady M. Images in cardiology. Twiddler's syndrome in a patient with an implantablecardioverter defibrillator. Heart. 2006;92:826.

17. Vural A, Agacdiken A, Ural D, Komsuoglu B. Reel syndrome and pulsatile liver in a patient with a two-chamber pacemaker. Jpn Heart J. 2004;45:1037-42.

18. Parsonnet V. A stretch fabric pouch for implanted pacemakers. Arch Surg. 1972;105:654-6.

19. Higgins SL, Suh BD, Stein JB, Meyer DB, Jons J, Willis D. Recurrent twiddler's syndrome in a nonthoracotomy icd system despite a dacron pouch. Pacing Clin Electrophysiol. 1998;21:130-3. 